\title{
Stefan Sołtyszewski
}

\section{Konferencja Biskupów}

Prawo Kanoniczne : kwartalnik prawno-historyczny 10/3-4, 29-43

1967

Artykuł został zdigitalizowany i opracowany do udostępnienia w internecie przez Muzeum Historii Polski w ramach prac podejmowanych na rzecz zapewnienia otwartego, powszechnego i trwałego dostępu do polskiego dorobku naukowego i kulturalnego. Artykuł jest umieszczony w kolekcji cyfrowej bazhum.muzhp.pl, gromadzącej zawartość polskich czasopism humanistycznych i społecznych.

Tekst jest udostępniony do wykorzystania w ramach dozwolonego użytku. 


\section{Ks. STEFAN SOETYSZEWSKI}

\section{KONFERENGJE BISKUPÓW}

Treść: 1. Pojęcie Konferencji Biskupów. --2, Geneza instytucji Konferencji Biskupów. - 3. Struktura prawna Konferencji Biskupów. a) Skład personalny, b) Statut, c) Stała Rada Biskupów, d) Komisje biskupie, e) sekretariat generalny. — 4. Kompetencje Konferencji Biskupów. - 5. Władza prawodawcza Konferencji Biskupów.

\section{Pojęcie Konferencji Biskupów}

Wyraz łaciński „conferentia“ znaczy zebranie, zgromadzenie. Konferencją biskupów czyli zebraniem lub zgromadzeniem biskupów nazywano sporadyczne lub okresowe zebrania biskupów jakiegoś narodu lub kraju, zgromadzonych $w$ celu wymiany rad i informacji wzajemnych w sprawach kościelnych danego terytorium.

Z czasem Konferencje te ustaliły sobie ogólny „modus agendi“, dotyczący czasu zebrań, struktury personalnej, wydawania ujednoliconych decyzji. W okresie przed Soborem Watykańskim II istniały przeważnie konferencje biskupie narodowe. Sobór postuluje tworzenie tam, gdzie ich nie ma, konferencji tego rodzaju, a także w razie potrzeby, konferencji międzynarodowych o charakterze regionalnym czy nawet kontynentalnym. ${ }^{1}$

Te ostatnie istnieją już w Ameryce Południowej, pod nazwą Konferencje Biskupów Ameryki Lacinskiej ( w skrócie literowym GELAM) oraz $w$ Afryce. ${ }^{2}$

Terminologia: „Conferentiae Episcoporum“ „Confereniae Episcopales" stosowana jest $w$ dokumentach Stolicy Ap. i soborowych takich jak: Dekret Kongregacji Konsystorskiej z 13.VII.1963 ${ }^{3}$; M.P. „Pastorale munus" z 30.XI.1963 " ; M.P. „Apostolica sollicitudo" z 15.VIII.1965 " ; dekret „Christus Dominus" z 28.X.1865"

1 Decretum de pastorali Episcoporum munera in Ecclesia "Christus Dominus" de die 28. X. 1965, n. 37 i 38,5 : AAS 58/1966/693 i 694.

${ }_{2}$ Tygodnik Powszechny 21 (1967) nr. 13. s. 6.

${ }^{3}$ AAS 55 (1963) 656.

4 AAS 56 (1964) 10, n. 32.

AAS 57 (1965) 775

' AAS 58 (1966) 692-694. 
M.P. „Ecclesiae sanctae“ z 6.VIII.1966"; regulamin Synodu biskupów z 8.XII.1966 . Soborowa konstytucja liturgiczna z 4.XII.1963 nie używa tej nomenklatury, lecz Konferencje Biskupów nazywa „kompetentnymi zgromadzeniami biskupów na danym terytorium" ", lub po prostu „,kompetentną władzą kościelną terytorialną" (competens auctortias ecclesiastica territorialis) ${ }^{10}$. Te zgromadzenia zarządzenie wykonawcze "Liturgiam sacram" nazywa „narodowymi" 11. Również Konstytucja dogmatyczna „de Ecclesia“ nie używa terminologii „conferentiae“ lecz „coetus episcopales" 12 .

Konferencje Biskupów oficjalnej definicji rzeczowej nie posiadały. Formuluje ja dopiero soborowy dekret "Christus Dominus“. Według tegoż dekretu: „Konferencja Biskupów jest jakby zespołem, w którym czcigodni pasterze danego narodu czy terytorium lącznie wykonują swe pasterskie zadania dla pomnożenia dobra, udzielonego ludziom przez Kościół, głównie poprzez odpowiednio dostrojone, do bieżących okoliczności czasu, formy i sposoby apostolatu" " ${ }^{13}$. Nie jest to bynajmniej definicja we wlaściwym sensie, ale pewien opis analityczny, trudny do oddania w języku polskim.

\section{Geneza instytucji Konferencji Biskupów}

Ciekawa jest ta instytucja, możnaby o niej powiedzieć, że już istniala zanim sie narodzila. Kodeks Prawa Kanonicznego nie zna tego rodzaju instytucji, ani jej terminologii, aczkolwiek jego Index analitico-alphabeticus zawiera hasło: "Conferentiae Episcoporum", lecz w odniesieniu do kanonu 292. Kanon ten mówi o jednym z 3 rodzajów zebrań biskupów, a mianowicie o zebraniach biskupów prowincji kościelnej, które winny być zwoływane przez metropolitę lub najstarszego sufragana co 5 lat dla narad nad sprawami metropolii i przygotowania wniosków na przyszly synod prowincjonalny. W skład zebrań biskupów prowincji wchodzą ordynariusze miejsca (k. $292 \S 1$ ) przynależnych diecezji; biskupi nie mający metropolity; opaci i prałaci niezależni oraz arcybiskupi nie posiadający sufraganów, którzy za uprzednią aprobatą Stolicy Apostolskiej wybiora sobie sąsiedniego Metropolitę i będą brać udział w zebraniach biskupów danej prowincji (k. $292 \S 2$

'AAS 58 (1966) 773.

${ }^{8}$ L'Osservatore Romano z 24. XII. 1966, n. 296, s. 2.

${ }^{3}$ AAS 56 (1964) 106, art. $22 \S 2$.

10 Tamże art. $36 ; 41,1 ; 44 ; 63,6 ; 77$.

11 AAS 56 (1964) 143.

12. AAS 57 (1965) 29, n. 23.

${ }^{13}$ Dekret "Christus Dominus“, jak wyżej, s. 693, n. 38, 1․ (w thumacz. pol. Miesięcznik pasterski plocki 7 (1967) nr. 1-2, s. 15. 
i k. 285) ${ }^{14}$. Kodeks Prawa Kanonicznego tego rodzaju zebrania nazywa "conventus Episcoporum provinciae" (k. 1507), natomiast terminu "conferentiae" używa w odniesieniu do zebrań duchowieństwa kondekanalnego "quos collationes seu conferentiae vocant" (k. 131). Oprócz zebrań biskupów prowincji Kodeks zna jeszcze 2 ich rodzaje, a mianowicie:

1) Synod plenarny (k. 281-282) i

2) Synod prowincjonalny (k. 283-286).

Synod plenarny lub narodowy jest to zebranie biskupów kilku prowincji lub wszystkich prowincji danego kraju, zwołane przez legata papieskiego, który przewodniczy na synodzie (k. 281). W synodzie takim $\mathrm{z}$ prawa, z głosem decydującym, biorą udzial oprócz legata, metropolici, biskupi rezydencjalni, których moga reprezentować koadiutorzy lub też biskupi pomocniczy, następnie administratorzy Ap., opaci i prałaci niezależni, wikariusze i prefekci Ap. oraz wikariusze kapitulni (k. 282 § 1). Również biskupi tytularni, przebywający na danym terytorium biorą udzial $w$ synodzie plenarnym z glosem decydującym, jeśli inaczej nie postanowiono w akcie konwokacyjnym (k. 282 \& 2). Inni duchowni, ewentualnie powolani na synod, maja glos doradczy (k. 282 §3). Czas odbywania synodów plenarnych nie jest kanonicznie oznaczony, a zezwolenie na jego zwołanie daje papież (k. 281). Takie synody odbyly się w Arles (314), w Kartaginic (V w.) w Toledo (VI i VII), w Baltimore (1852, 1866, 1884), w Irlandii (1875), w Australii (1885, 1895) w Rzymie dla Ameryki Lacińskiej (1899), w Chinach (1929), tego rodzaju synod polski odbył się w Częstochowie w r. 1936.

Synod prowincjonalny jest to zebranie wszystkich biskupów danej prowincji kościelnej, zwołane przez metropolite, lub z braku tegoż, przez najstarszego pod względem promocji, sufragana (k. 284). Ci wyznaczają czas i miejsce zebrania, zwolują synod i przewodniczą nań $\left(\mathrm{k} .284,1^{0}, 2^{\circ}\right)$. Sklad personalny synodu prowincjonalnego stanowią:

a) czlonkowie obowiązkowi z glosem decydującym: metropolita, ordynariusze miejsca, biskupi, którzy nie mają metropolity, opaci i prałaci niezależni, oraz arcybiskupi, którzy nie mają sufraganów, jeśli wybrali, raz na zawsze, za zgoda St. Ap. metropolitę, który zwołuje synod (k. 285, 286);

14 Włochy, dekretem Kongregacji Konsystorskiej z dnia 15. II. 1919 zostaly podzielone na 15 regionów, w których każdego roku mają odbywać się zebrania biskupów (AAS II (1919) 72-74).

it B e z a c R., Les conferences episcopales nationales, Revue de droit canoniquea 15 (1965) 308. 
b) czlonkowie obowiązkowi z głosem doradczym : 2 kanoników z każdej kapituły lub 2 konsultorów diec., wyżsi przelożeni kongregacji monastycznych oraz wyżsi przełożeni zakonów kleryckich, wyjętych (k. $286 \S 3$ i 4);

c) członkowie fakultatywni z głosem decydującym: biskupi tytularni, rezydujący $w$ prowincji, wezwani przez przewodniczącego za zgodą wiẹkszości synodu, posiadającej głos decydujący (k. $286 \quad \S 2$ ). Instytucja synodów prowincjonalnych jest bardzo stara, istnieje permanentnie od IV w..$^{15}$ Według Kodeksu synod prowincjonalny winien się odbywać co 20 lat (k. 283).

Jeśli chodzio moc prawną decyzji tych 3 rodzajów zebrań biskupich, to należy podkreślić, że pierwsze $z$ nich, to jest zebranie biskupów prowincji kość. nie posiada wladzy prawodawczej, a decyzje jego są prostymi dyrektywami praktycznymi, bez prawnego obowiązywania, Natomiast synod plenarny i prowincjonalny posiada zwyczajną wladzę prawodawczą na danym terytorium, a ojcowie synodalni mają władzę wydawania dekretów, z mocą prawnie obowiązująca, dotyczacych ksztaltowania obyczajów, karcenia nadużyć, rozstrzygania kontrowersji, zachowania jednej i tej samej karności (k. 290). Zanim uchwalone dekrety zostaną promulgowane przez synod plenarny czy prowincjonalny winny być one przesłane do wglądu St. Ap. Kongregacja soboru rozważa je i przegląda, udzielając im „,nihil obstat", wtedy dopiero moga być promulgowane (k. 291).

Narodowe Konferencje Biskupów można teoretycznie przyrównać do wyżej omówionych zebrań biskupich. Zwłaszcza do synodu plenarnego, który gromadzi biskupów wszystkich prowincji danego kraju i posiada zwyczajna władze prawodawczą, lecz bez obecności legata St. Ap. i uprzedniego zezwolenia na zwolanie synodu. Jak również do zebrania biskupów prowincji kościelnej, poszerzonej do terytorium całego narodu, lecz bez władzy prawodawczej. Zestawienie Konferencji Biskupów ze zgromadzeniami biskupów już istniejącymi pozwoli na lepsze zrozumienie nowości tej pierwszej, a powołanie jej nie znosi bynajmniej organizmów biskupich funkcjonujących dotąd. Sobór Watykański II wyraża życzenie, aby synody nabraly nowej mocy do bardziej skutecznego wspierania wzrostu wiary i zachowania karności w różnych Kościołach, stosownie do okoliczności czasu ${ }^{16}$.

Przed Soborem wat. II w wielu krajach, na podstawie zwyczaju, istniały Narodowe Konferencje Biskupów. Znane byly: Konferencja biskupia episkopatu niemieckiego, obradująca w Fuldzie,

${ }_{15}$ Tamże, Revue de droit canonique, s. 309.

16 Dekret „Christus Dominus" j.w., 692, n. 36. 
Narodowa Konferencja Biskupów Francuskich, Konferencja Biskupów w Polsce i inne. Konferencje te miały charakter zebrań biskupich po myśli k. 292, z tym, że obejmowały cały poszczególny kraj. Za tego rodzaju Konferencjami Biskupów opowiadal się . kard. Frings $w$ czasie debaty soborowej. ${ }^{17}$

$\mathrm{Na}$ Soborze zagadnieniem Konferencji Biskupów „ex professo“ zajmowała się Komisja soborowa dla spraw biskupów i zarządu diecezji. W czasie II-ej sesji -- w dniu 5 listopada 1963 -- na 60-tej Kongregacji generalnej wniesiono pod obrady schemat „O biskupach i zarządzie diecezji“, którego III-ci rodział traktował o $\mathrm{Na}$ rodowych Konferencjach Biskupów. ${ }^{18} \mathrm{~W}$ dniu 12.XI.1963 na 65-tej Kongregacji generalnej rozpoczęła się debata nad tym rozdziałem i w dyskusji zabierali głos kardynałowie: Suenens (Belgia), Mac Intyre (St. Zjedn.), Meyer (St. Zjedn.), Gracjas (India), Landazuri Ricketts (Peru); biskupi: Slipyj (Ukraina), Hervas (Hiszpania), Kak (Austria), Volk (Niemcy), Tchidimbo (Gwinea), Zaspe (Argentyna), Cahill (Australia). ${ }^{19}$

$\mathrm{Na}$ nastepnej Kongregacji trwała kontynuacja debaty na ten sam temat, w czasie której przemawiają kardynalowie: Spellman (St. Zjedn.) i Frings (Niemcy), oraz biskupi : Olaecha (Hiszpania), Pildaiñ (Hiszpania), Bianchi (Chiny) i inni; bp Carli wystęuje w przemówieniu przeciw zdaniu niektórych mówców, że konferencja biskupia opiera się na zasadzie kolegialności. ${ }^{20}$

W dniu 14.XII. 1963 r., na 67-tej Kongregacji generalnej na temat Narodowych Kongregacji Biskupich zabiera glos kardynal Stefan Wyszyński i wygłasza "Uwagi o Konferencjach Biskupów w Polsce“", zatytułowane: "Quaedam de Conferentiis Episcoporum in Polonia" ${ }^{21}$. Oto streszczenie niniejszego przemówienia: Pierwsze Konferencje przy obecności wszystkich biskupów polskich odbyły się $w$ roku 1917. Odtąd zwolywane były 2 lub 3 razy do roku. Obecnie Konferencje Biskupów rezydencjalnych odbywają sie 6 razy do roku. Poza tym wszyscy biskupi polscy raz do roku zbierają się na dwudniową sesję w Sanktuarium Jasnogórskim, która poprzedzają trzydniowe rekolekcje. Sesje plenarne Konferencji przygotowuje Komisja Główna składająca się z 9 biskupów. Wszystkie sprawy rozdzielone są pomiędzy poszczególne komisje.

${ }_{17}$ Revue de droit canonique, s. 312.

18 Kronika soborowa (29. IX.-4. XII. 1963), Prawo Kanoniczne, 7 (1964) nr. $1-2$, s. 381.

ig Tamże, s. 382.

20 Tamże.

${ }^{21}$ W y s z y ński S. kard., Quaedam de Conferentiis Episcoporum in Polonia, Oratio habita in sessione generali Concilii Vaticani II, die 14 Novembris A. D. 1963 (maszynopis autoryzowany).

3 - Prawo kanoniczne nr 3-4 
Komisje składają się przede wszystkim z biskupów pomocniczych i innych ekspertów; przygotowują one schematy dla całej Polski, które poddawane są dyskusji na sesjach plenarnych. Dla koordynacji stosunków pomiędzy Kościołem a Państwem istnieje Komisja mieszana, składająca się z 2 biskupów i 2 ministrów. Moc postanowień, ferowanych na sesjach plenarnych, jest ,raczej natury moralnej niż prawnej". Konferencje nie posiadają statutu, jednak wszyscy biskupi na obrady sesji przybywaja; schematy duszpasterskie, przyjęte przez sesję plenarną, realizują, ustalony sposób działania $w$ stosunkach pomiędzy Kościołem a Państwem, zachowują.

W ogniu soborowej dyskusji schemat o biskupach i zarządzie diecezji okazal się niezadawalający, przeto został odesłany do Komisji w celu przepracowania go na nowo. Po przeredagowaniu powrócil on znowu pod obrady w auli soborowej, dopiero na III-ciej sesji w dniu 18.IX. 1964 r., ale pod zmienionym tytułem: „de pastorali Episcoporum munere in Ecclesia" ${ }^{22}$. Nowy schemat zawiera główne elementy schematu ,o biskupach i zarządzie diecezji oraz drugiego „de cura animarum" i składa się ze wstẹpu i 3 rozdziałów:

1. Biskupi w kościele powszechnym,

2. Biskupi $w$ ich diecezji,

3. Biskupi współpracujący dla dobra większej ilości diecezji. ${ }^{23}$

Wlaśnie $w$ tym ostatnim rodziale jest mowa o Konferencjach biskupich. Perspektywy nowego schernatu na temat Konferencji były zupelnie inne (n. 37). Podkreślono w nim przydatność Konferencji narodowych, które mają uzasadnienie „w niemożliwości wprost, widocznej coraz bardziej, aby jeden biskup decydowal o wielu sprawach, które sa aktualne nietylko w jego diecezji" 24. Schemat ten czyli projekt dekretu "Christus Dominus" przytacza w przypisach niektóre $z$ tych kwestii np.: te, które dotyczą calego narodu, sprawy szkolne, administracja ogólna, ogłaszanie nowych przypisów w stosunku do poprzedniego statusu, czy też wyraźnie różniących się od statusu ościennego narodu, rzeczy, które mogą zadziwić lub zaskoczyć wiernych. ${ }^{25}$ Artykuł 37 tegoż schematu stwierdza, że Konferencje biskupie funkcjonuja tu $\mathrm{i}$ tam $\mathrm{i}$ to z dużym pożytkiem i wprost kanonizuje ten fakt, życząc sobie, aby się upowszechnil. ${ }^{26}$ Rozdział 3 w którym jest mowa „O Kon-

${ }^{22}$ Kronika soborowa (14. IX.-21. XI. 1964), Prawo Kanoniczne 7 (1964) nr. 3-4, s. 193.

${ }^{23}$ Revue de droit canonique, s. 306.

${ }^{24}$ Tamże.

2ó Tamże, s. 313.

28 Tamże (,summopere expedire censet" 
ferencjach biskupich" ulegał różnym poprawkom, aż zostal poddany pod głosowanie 1.X.1965 r. i otrzymal aprobatę Ojców soborowych, uzyskując 2.060 głosów - pro i 20 - contra. ${ }^{27}$

Schemat "de pastorali Episcoporum munere in Ecclesia", zawierający postanowienia o Konferencji Biskupów, stał się dekretem "Christus Dominus" po uroczystej aprobacie Ojców soborowych i promulgacji przez Pawła VI $w$ dniu 28. X. 1965.28

Centralnym punktem 3 rozdz. "Chr. D." są Konferencje Biskupów. Soborowy dekret „Christus Dominus“ stanowi „magnam cartam" w dziejach Konferencji Biskupów: definiuje jej pojęcie; określa Strukturę prawną, zakreśla kompetencję, nadaje byt prawny (ens iuridicum), eryguje nową osobę moralną kolegialną w Kościele ${ }^{29}$. Dekret „Christus Dominus" wszedł w życie od 11.X. 1966 r., wprowadzony zarządzeniem wykonawczym M.P. Pawła VI „Ecclesiae sanctae", w którym są zawarte normy, dotyczące Konferencji Biskupów ${ }^{30}$.

Dekret "Christus Dominus" jest duszpasterską a plikacją III rozdz. Konstytucji soborowej o Kościele, który mówi o „hierarchicznym ustroju Kościoła, a w szczególności o biskupach" "31. Konferencje Biskupów sięgają korzeniami do tej Konstytucji dogmatycznej, z niej bowiem płyna zasady, które są ich podbudową. Konstytucja głosi, że: „Kolegialna jedność przejawia się również we wzajemnych stosunkach poszczególnych biskupów z Kościołami partykularnymi i z Kościołem powszechnym", a więc i w Konferencjach biskupich, które są prawnym przejawem kolegialności, tak, jak w szerszym jeszcze zakresie jest nim synod Biskupów. Konstytucja konkluduje że: „Konferencje Biskupów (coetus Episcopales) mogą dziś wnieść różnorodny i obfity wkład, aby kolegialność została doprowadzona do konkretnego zastosowania" "33. Właśnie takie konkretne zastosowanie posiada obecnie kolegialność w strukturze i działaniu Konferencji Biskupów.

\section{Struktura prawna Konferencji Biskupów}

a) Sklad personalny

Konferencja Biskupów obejmuje zespól biskupów jakiegoś narodu lub terytorium, który lącznie wykonuje swoją funkcje dusz-

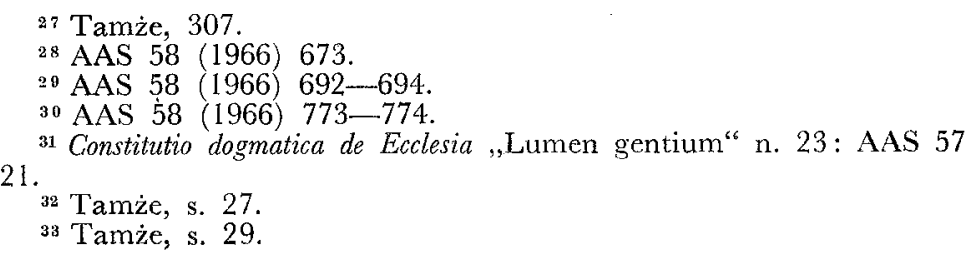

32 Tamże, s. 27

33 Tamże, s. 29 
pasterską. Konferencje narodowe kształtują się samodzielnie bez aprobaty St. Ap.; konferencje zaś wielu narodów mogą być ustanowione tylko za aprobatą St. Ap., do której należy ustanowienie dla nich specjalnych przepisów ${ }^{34}$. Pożądanym jest, aby konferencje biskupie na terenach misyjnych łączyly się $w$ grupy organiczne, wg rejonów społeczno-kulturalnych, przy czym ma im pomagać Kongregacja Rozkrzewiania Wiary. ${ }^{35}$

Skład personalny Narodowych Konferencji Biskupich ogólnie określa już Zarządzenie wykonawcze do Konst. liturgicznej, stanowiąc, że biorą $w$ niej udzial i głosują oprócz biskupów rezydencjalnych, również ci o których mówi kan. 292; lecz mogą być do nich powolani koadiutorzy i sufragani ${ }^{36}$.

W skład Konferencji Biskupów według dekretu „Christus Dominus" jako czlonkowie z prawa, wchodza:

1. wszyscy ordynariusze miejsca jakiegobądź obrządku na darzoną nym terytorium;

2. koadiutorzy i biskupi pomocniczy;

3. inni biskupi tytularni, wykonujący specjalną funkcję, powierzona sobie przez St. Ap. lub Konferencje ${ }^{37}$.

Biskupi tytularni np. spełniający funkcję biskupa polowego czy też moderatora narodowego Akcji Katolickiej, sa $z$ prawa czlonkami Narodowych Konferencji Biskupich ${ }^{38}$. Natomiast legaci papiescy ${ }^{39}$, czy wikariusze generalni ${ }^{40}$; jak również biskupi rezydencjalni, lecz dymisjonowani, nie są czlonkami tej instytucji ${ }^{41}$.

Co do kompetencji członkowskiej, to jest ona dwustopniowa:

1. jedni tj. ordynariusze miejsca, jak również koadiutorzy, mają głos decydujący;

2. biskupi pomocniczy i inni, mający prawo udziału $w$ konferencjach, będą mieć glos decydujący lub doradczy, lecz to ma być zadecydowane przez statut poszczególnych konferencji ${ }^{41}$.

b) Statut

Każda Konferencja Biskupów winna sporządzić wlasny statut i przedstawić go do wglądu Stolicy Ap. ${ }^{42}$. Wyrażenie Dekretu oraz Zarządzenie wykonawczego ,statuta ab Apostolica Sede re-

${ }^{34}$ M.P. „Ecclesiae Sanctae“: AAS 58 (1966) 774, art. $41 \S 4$.

3s Tamże, s. 786.

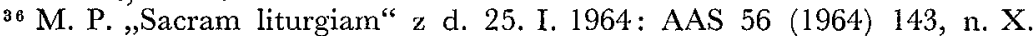
Zam. 256 JA 5

37 Dekret "Christus Dominus“" n. 38, 2: AAS 58 (1966) 693.

${ }^{38}$ Revue de droit canonique, s. 314.

${ }^{9}$ Dekret "Christus Dominus" n. 38, 2.

40 Tamże.

${ }^{41}$ Revue de droit canonique, s. 314; Dekret "Christus Dominus", n. 38, 2

42 Tamże, n. 38, 3 ; por. Revue.., s. 311 i 312 : ,Chaque Conference d'Evêques établira ses propres statuts à revoir par le Siege Apostolique". 
cognoscenda", zdaje się świadczyć, iż nie chodzi tu o aprobatę we właściwym znaczeniu, lecz o uzyskanie „nihil obstat“ ${ }^{43}$.

$\mathrm{Z}$ drugiej strony Annuario Pontificio ${ }^{44}$, wymieniając 64 istniejące już Konferencje Biskupów, zaznacza, że 39 spośród nich posiada „statuti approvati ad experimentum“, co świadczy o ich zatwierdzeniu przez Stolice Apostolską. Poza tym 2 Konferencje maja statuty zatwierdzone bez dodatku „ad experimentum“, sa to statuty Konferencji Biskupów Irlandzkich, zatwierdzone w r. $1882{ }^{45}$ i Stanów Zjednoczonych, zatwierdzone w r. $1922{ }^{46}$.

Niewątpliwie wyrażenie "statuta recognoscenda" w formie lagodniejszej oznacza to samo co "statuti approvati“.

Konferencje biskupów francuskich, nie czekając na promulgacje dekretu "Christus Dominus" zebrała się i uchwaliła swój statut ${ }^{47}$. Konferencja Episkopatu w Polsce statutu nie posiada, ale obecnie, zgodnie z uchwałą soboru, zostanie opracowany. ${ }^{48}$. Konferencje, które już posiadają statuty winny je odnowić $\mathrm{w} / \mathrm{g}$ norm, wydanych przez Sobór i przesłać do zatwierdzenia St. Ap. ${ }^{49}$.

W statucie, oprócz innych środków, dla skuteczniejszego działania, winny być przewidziane wydziały np. Stała Rada Biskupów, Komisje biskupiej Sekretariat generalny ${ }^{50}$.

\section{c) Stała Rada Biskupów}

Trzonem Konferencji Biskupów jest Rada Biskupów, której nazwa świadczy o stałości instytucji, a której zadania będą się niewątpliwie pokrywać z zadaniami Komisji Głównej Konferencji Episkopatu Polski, składającej się z dziewięciu biskupów ${ }^{51}$. Zadaniem tej komisji jest:

1. ustalanie porządku obrad;

2) proponowanie schematów;

3) badanie stanu Kościoła i jego stosunków z władzą cywilną z $^{52}$ i t. p.

d) Komisje biskupie

Konstytucja sob. liturgiczna zalecila Konferencjorn ustano-

${ }^{43}$ Tamże; M.P. „Ecclesiac sanctae“ n. 41, 1).

44 Annuario Pontificio, Citta del Vaticano 1967, s. 798-804;

4s̃ Tamże, s. 801 .

46 Tamże, s. 804.

47 Revue de droit canonique, s. 312 , nota 9.

${ }^{8}$ Quaedam de Conferentiis Episcoporum in Polonia (maszynopis s. 2) ; G h o romańs i Z., Z dziejóre $i$ prac Konferencji Episkopatu Polski, Ateneum Kapł., 58 (1966) 162.

${ }^{49}$ M.P. „Ecclesiae Sanctae“: AAS 58 (1966) $774 \S 2$.

so Dekret "Christus Dominus", n. 38, 3.

${ }^{51}$ Quaedam de Conferentiis Episcoporum in Polonia (maszynopis s. 1)

32 Tamże. 
wienie Komisji liturgicznej. ${ }^{53}$ Zarządzenie wykonawcze „Ecclesiae sanctae" zaleca utworzenie specjalnych komisji w lonie Konferencji. Np. przy każdej Konferencji biskupiej winna być ustanowiona komisja do której zadań należy: badanie potrzeb różnych diecezji w celu zaradzenia braku duchownych; oraz wykonanie postanowień zatwierdzonych przez Konferencję, odnośnie rozdziału kleru ${ }^{54}$. W ramach Konferencji Biskupów winna znajdować się komisja biskupia dla spraw misji, do której należy kooperacja $w$ tej dziedzinie pomiędzy diecezjami danego terytorium. ${ }^{55}$ Konferencja może również ustanowić kapłana lub komisje dla spraw emigracji i podróżujacych w trosce o ich dobro duchowe. ${ }^{56}$ Jeśli zajdzie potrzeba Konferencja winna powołać Komisję dla zbadania i rozgraniczenia diecezji..$^{57}$ Może oczywiście istnieć w łonie Konferencji cały szereg innych Komisji, tak zresztą jak istniały i dotychczas. Ks. Kardynal Wyszyński w swoim przemówieniu soborowym „O Konferencji Biskupów w Polsce" wyliczył ich 11. Sa to: 1) Komisja soborowa, 2) duszpasterska, 3) katechetyczna, 4) mariologiczna, 5) zakonna, 6) dla sem. i studiów, 7) liturgiczna, 8) charytatywna, 9) dla spraw KUL-u, 10) prawna $\mathrm{i}$ administracyjna, 11) wydawnicza $\mathrm{i}$ inne ${ }^{58}$. Ks. Biskup Choromański, sekretarz Konferencji Episkopatu Polski, podaje, że oprócz wyżej wymienionych, istnieją jeszcze: 12) komisja prasowa, 13) komisja duszpasterstwa akademickiego, 14) komisja instytucji polskich w Rzymie, 15) komisja filmu, telewizji i radia, 16) komisja trzeźwości, 17) komisja artystyczno-konserwatorska, 18) komisja powolań, 19) komisja dla rewizji K.P.K. 20) komisja apostolstwa świeckich oraz 21) komisja duszpasterstwa emigracji.

\section{e) Sekretariat Generalny}

Ważne miejsce $w$ strukturze Konferencji Biskupów posiadają Sekretariaty Generalne; do nich oprócz zwyklých zadarí w łonie Konferencji, będzie należalo ułożenie w sposób odpowiedni i adekwatny stosunków pomiędzy Konferencjami, zwłaszcza sąsiednich narodów ${ }^{60}$. Winny one:

a) porozumiewać się $w$ sprawach funkcjonowania duszpasterstwa;

${ }^{\circ 3}$ Cont. „Sacrosanctum Concilium": AAS 56 (1964) 112.

54 AAS 58 (1966) 759, n. 2.

55 Tamże, s. 784, n. 9.

se Tamże, s. 763, n. 9.

57 Tamże, n. $12 \S 1$.

${ }_{58}$ Quaedam de Confereniiis Episcoporum in Polonia, s. 1.

sø Choromański Z., Z dziejów $i$ prac Konferencji Episkopatu Polski, s. 163.

${ }^{60}$ M.P. „Ecclesiae Sanctae": AAS 58 (1966) 774. 
b) wzajemnie przesylać sobie postanowienia Konferencji;

c) wskazywać na problemy, które $w$ danym momencie mają specjalne znaczenie;

d) wskazywać na niebezpieczeństwa, blędy, kntóro mogą zagrozić innym krajom;

e) informować o inicjatywach, które $w$ podobnych wypadkach - moga być przydatne innym Konferencjom ${ }^{61}$.

\section{Kompetencje Konferencji Biskupów}

Pragnę przedstawić kompetencje Konfefencji Biskupów w porządku chronologicznym tj. $w$ takiej kolejności $w$ jakiej były one udzielane lub normowane przez Stolicę Apostolską czy przez Sobór Wat. II. Uprawnienia te lub ich normalizacje zawieraja nastepujące dokumenty: Dekret Kongregacji Konsystorskiej, M.P. "Pastorale munus“, Konstytucja liturgiczna, M.P. „Apostolica sollicitudo“, Dekret „Christus Dominus“, M.P. „Ecclesiae Sanctae" oraz Regulamin Synodu Biskupów.

Dwa pierwsze dokumenty mówią o kompetencji w sprawie alienacji majątku kościelnego. Dekret Kongregacji Konsystorskiej na skutek dewaluacji pieniądza podniósł sumę 30,000 fr. szwajcarskich do 66.000 wartości maj. kość., ponad którą przy alienacji decyduje Stolica Ap. (por. kan. 1532). Koferencje narodowe biskupie mają określić jakiej sumie w lokalnych dewizach odpowiada ta podwyższona suma i powiadomić o tym St. Ap. ${ }^{61}$ M.P. „Pastorale munus“ idzie dalej i wśród 40 uprawnień, udzielonych biskupom rezydencjalnym w 32 z kolei zezwala biskupom na alienację majątku kościelnego o wartości do takiej sumy, jaką ustali narodowa lub regionalna Konferencja Biskupów i którą zatwierdzi St. Ap. ${ }^{63}$.

W/g soborowej konstytucji liturgicznej, na mocy władzy danej przez prawo, kierownictwo nad liturgia na danym terytorium należy również ,ad competentes varii generis territoriales Episcoporum coetus legitime constitutos ${ }^{64}$. Wprawdzie jest tu mowa o różnych zrgomadzeniach biskupów, lecz w interpretacji tekstu położony jest akcent na zebrania biskupie nowego rodzaju, na konferencje biskupie narodowe. ${ }^{65}$ Narodowe Konferencje Biskupów decydują o użyciu i sposobie zastosowania języka narodowego

\footnotetext{
"11 Tamże.

*2 Dekret Kongregacji Konsystorskiej z dn. 13. VII. 1963: AAS 55 (1963) 656. Kwota ta $\mathrm{w}$ przeliczeniu na walute amerykańską wynosi 15.180 dol.

${ }^{63}$ M.P. „Pastorale munus" z d. 30. XI. 1963: AAS 56 (1964) 10.

6. Konst. "Sacrosanctum Concilium“, n. 22 § 2: AAS 56 (1964) 106.

${ }^{65}$ Revue, s. 305.
} 
w liturgii, lecz za aprobata St. Ap. ${ }^{66}$ Przekład tekstu lacińskiego, liturgicznego, na język narodowy aprobuje Narodowa Konferencja Biskupów. ${ }^{67}$.Zarządzenie wykonawcze Konstytucji liturgicznej interpretuje to $\mathrm{w}$ ten sposób, że przetlumaczony tekst, aprobowany przez Konferencje biskupia, bedzie prawnie aprobowany $\mathrm{i}$ konfirmowany przez St. Apostolską ${ }^{68}$. Narodowa Konferencja Biskupów posiada prawo przyswojenia czyli wprowadzenia czegoś z tradycji i ducha narodu do liturgii za zgodą St.Ap. ${ }^{60}$ Do jej uprawnień należy dostosowanie, do nowego rytuału rzymskiego, rytuału partykularnego, również co do języka, ${ }^{70}$ jak również sporządzenia nowego rytu przy udzielaniu ślubu ${ }^{71}$. Do prawnego wydania dekretów, w sprawach liturgicznych, wymagane są $2 / 3$ głosów, oddanych w tajnym głosowaniu ${ }^{72}$.

Konferencje biskupie wybierają swoich reprezentantów do Synodu Biskupów: jednego na 25 członków Konferencji; 2 na 50 członków; 3 - na 100 członków; 4 - na ponad 100 czlonków Konferencji. ${ }^{73}$ Regulamin Synodu Biskupów ${ }^{74}$ szczególowo określa wybór reprezentantów. Mają oni być wybierani na plenarnej sesji $\mathrm{w}$ tajnym glosowaniu, zgodnie $\mathrm{z}$ kan. $101 \S 1,1^{\circ}$. W imieniu wybranych przewodniczacy Konferencji powiadomi Sekretarza. generalnego Synodu o ich wyborze, w zasadzie za pośrednictwem legata papieskiego, $\mathrm{i}$ to przynajmniej na 2 miesiące przed rozpoczęciem Synodu. Nazwiska wybranych nie będą publikowane, dopóki ich wybór nie zostanie ratyfikowany przez papieża.

Przewodniczący Konferencji biskupich narodowych i międzynarodowych sa $z$ urzędu delegatami na zebranie nadzwyczajne Synodu Biskupów ${ }^{75}$. Kwestie, które będą rozpatrywane na Synodzie, uprzednio mają być debatowane na Konferencjach biskupich, które przedsiębiorą wspólną opinię na ich temat. Po skończonej dyskusji członek Synodu przekaże wniosek Konferencji na piśmie Sekretarzowi generalnemu, zgodny z opinią Konferencji, którą reprezentuje ${ }^{76}$. Annuario Pontificio z r. 1967

${ }^{6} 6$ Konst. „Sacrosanctum Concilium", n. $36 \$ 3$.

67 Tamże, n. 36 § 4 .

${ }_{68}$ M.P. „Sacram liturgiam": ASS 56 (1964) 143.

6 Sob. konst. liturg., $n$. 40,1 .

70 Tamże, n. 63, 6 .

71 Tamże, n. 77.

${ }^{72}$ M.P. "Sacram liturgiam": AAS 56 (1964) 143.

73 AAS 57 (1965) 779.

${ }^{74} L$ 'Osservatore Romano z d. 25. XII. 1966 n. 296, s. 2.

${ }_{75}$ M.P. ${ }_{2}$ Apostolica sollicitudo": AAS 57 (1965) 779. 203.

${ }^{76}$ L'Osservatore Romano, s. 2.; por. Nouvelle revue théologique 88 (1966) 
podaje wykaz 64 Konferencji Biskupów. ${ }^{77}$ Sekretarz generalny Synodu Biskupów będzie utrzymywal kontakty z Konferencjami biskupimi ${ }^{78}$.

Do kompetencji Konferencji Biskupich poza tym należy m.in.:

1) rozpatrywanie sprawy wytyczenia prowincji kościelnych lub tworzenie nowych okręgów ${ }^{79}$;

2) wyznaczanie każdego roku sub secreto kandydatów na biskupów i wysyłanie listy do Rzymu ${ }^{80}$;

3) troska o uzgodnienie harmonijnej współpracy pomiędzy zakonami a klerem diecezjalnym ${ }^{81}$.

4) ustalenie odpowiednich przepisów dla administracji majątku kościelnego, odnośnie świadczeń na rzecz dzieł apostolatu, milosirrdzia lub na rzecz Kościołów, potrzebujących pomocy $^{82}$;

5) wydawanie zarządzeń, obowiązujących również zakonników nawet wyjętych, np. dotyczących kwesty na danym terytorium, uczęszczanie na publiczne widowiska i inne ${ }^{83}$;

6) proponowanie kandydatów na członków Kongregacji dla rozkrzewiania wiary ${ }^{84}$, i przesłanie jak najprędzej do Rzymu kwestii ogólniejszych, które na najbliższym zebraniu mogą być poruszane ${ }^{86}$

7) wydawanie norm, by zaradzić odpowiednio utrzymaniu materialnemu wszystkich duchownych ${ }^{87}$ i zabezpieczyć ich na wypadek choroby, niezdolności do pracy lub starości ${ }^{88}$;

8) studiowanie zagadnień duszpasterskich i komunikowanie uwag i wniosków na ten temat Stolicy Apostolskiej ${ }^{89}$;

9) co do dyscypliny pokutnej: zamiana postu i wstrzemięźliwości na modlitwę i uczynki miłosierne ${ }^{90}$.

Konferencje Biskupów posiadaja również kompetencje, a których było wyżej przy omawianiu komisji biskupich.

7 Annuario Pontificio, s. 798--804.

78 Informations catholiques internationales 1967, n. 284, s. 5.

7" Dekr.: "Christus Dominus" n. 41: AAS 58 (1966) 694-695.

${ }^{80}$ M.P. „Ecclesiae Sanctae“: AAS 58 (1966) 793, n. 10.

${ }^{81}$ Dekr. "Christus Dominus", n. 35, 5.

82 M.P. „Ecclesiae sanctae“: AAS 58 (1966) 761.

s3 Tamże, s. 770.

84 Tamże, s. 785.

85 Tamże: s. 786.

${ }_{86}$ Tamże, s. 783.

87 Tamże, s. 782.

88 Tamże.

Tamże, s. 775 .

so Konstytucja Apostolska „Poenitemini“ z 17. II. 1966: AAS 58 (1966) 183 


\section{Władza prawodawcza Konferencji Biskupów}

Szczególnym uprawnieniem konferencji biskupich, natury ogólniejszej, jest władza prawodawcza tychże. Co do charakteru władzy Konferencji Biskupów były różne zdania na Soborze. Kardynał Frings ${ }^{91}$ zalecal tego rodzaju Konferencje, jaka od dawna istnieje w Niemczech, gromadząc biskupów niemieckich w Fuldzie, która nie posiada władzy prawodawczej $w$ dosłownym znaczeniu. Tego zdania bylo wielu Ojców Soborowych. Kardynał Stefan Wyszyński mówil na Soborze o Konferencji Biskupów w Polsce, której postanowienia maja moc „potius naturae moralis quam iuridicae" ${ }^{\text {92. }}$.

Według zdania innych Ojców Soboru, aby nowy organ kościelny byl skuteczny, należy mu nadać strukture prawną $z$ władzą zwyczajną prawodawczą włącznie.

Sobór Watykański II zadecydowal rozwiązanie kompromisowe ${ }^{93}$, a mianowicie:

1. Decyzje Konferencji Biskupów, prawnie powzięte przez 2/3 biskupów, członków Konferencji z głosem decydującym, będa mialy moc zobowiązań prawnych tylko w trzech wypadkach:

a) jeśli prawo powszechne to przepisuje;

b) jeśli Stolica Apostolska specjalnym zarządzeniem z własnej inicjatywy o tym posanawia;

c) jeśli jakaś Konferencja Biskupów otrzyma na to zgodę Stolicy Apostolskiej, na wlasna prośbę ${ }^{94}$.

2. Decyzje, które otrzymały $2 / 3$ głosów, ale nie należą do tych trzech kategorii nie będa mialy mocy prawnej. Jak również decyzje poddawane pod gllsowanie, które nie otrzymaly 2/3 głosów; orientacje nad którymi nie przeprowadzono głosowania, ogólne wytyczne itp.

3. Przy glosowaniu wymagane są $2 / 3$ glosów wszystkich biskupów z głosem decydującym, należącym do Konferencji, a nie tylko obecnych aktualnie na posiedzeniu.

4. Postanowienia, które mają stać się prawem, muszą być wysyłane do aprobaty Stolicy Apostolskiej ${ }^{95}$, zanim zostaną promulgowane ${ }^{96}$.

\footnotetext{
${ }^{91}$ Revue de droit canonique, s. 312.

${ }^{92}$ Quaedam de Conferentiis Episcoporum in Polonia, s. 2.

${ }_{93} \mathrm{~V}$ e u ill o t P., Zasadnicze idee dekreiu soborozvego o pasterskiej funkcji biskupóze (w tłum. ks. H. Bogackiego) Ateneum Kapłańskie 58 (1966) 146.

${ }^{84}$ Dekret „Christus Dominus" n. 38, 4: AAS 58 (1966) 693.

${ }_{95}$ Tamże.

- Por. kan. 291 ; Revue de droit canonique, s. 316 :,
} 
Konkludując należy stwierdzić, że:

1. Konferencje Biskupów powstaly spontanicznie drogą zwyczaju.

2. Stolica Apostolska poczatkowo akceptowała je milcząco.

3. Egzystencję oficjalną nadaje im Konstytucja Jiturgiczna Soboru Watykańskiego II.

4. Byt prawny daje im soborowy dekret „Christus Dominus“, erygując nową osobę moralną $w$ Kościele, $z$ ważnym atrybutem ograniczonej władzy prawodawczej.

\section{Summarium \\ Conferentiae Episcorum}

Hoc in articulo de institulione Conferentiae Episcoporum tractatur, qui sequentibus capitibus constat:

1. Definitio Conferentiae Episcoporum.

2. Genesis institutionis Conferentiae Episcoporunl.

3. Structura iuridia Conferentiae Episcoporum:

a) Structura personalis, b) Statuta, c) Stabilis Consilium Episcoporum,

d) Commissiones episcopales, e) Secretariatus Generalis.

4. Competentiae Conferentiae Episcoporum.

5. Potestas legislativa Conferentiae Episcoporum.

Conclusiones huius tractatus sunt, ut sequitur:

1. Conferentiae Episcoporum spontaneae, via consuetudinis, ortae sunt.

2. Sedes Apostolica imprimis eas tacite acceptabat.

3. Existentia officialis a Constitutione liturgica eis data est.

4. Denique Conferentiae Episcoporum per Decretum conciliarem „Christus Dominus" ens iuridicum accipiunt. 